\title{
LA ESCRITURA DE JESÚS URZAGASTI: POÉTICA DE LA INTEMPERIE
}

\author{
María José Daona \\ (INVELEC-CONICET-UNT) \\ Tucumán, Argentina \\ mariajdaona@yahoo.com.ar
}

\begin{abstract}
RESUMEN/ ABSTRACT
En este trabajo analizo la poesía del escritor boliviano Jesús Urzagasti como una "poética de la intemperie". La escritura suprime los sentidos de desprotección y desamparo de la vida a cielo descubierto y construye una provincia, con un árbol en su centro, como espacio propicio para "habitar". Las imágenes de árboles y caballos dan cuenta de un territorio dejado atrás que vive en el interior del sujeto. Éste sucumbe, constantemente, al recuerdo de un pasado feliz protegido por el cielo y la tierra. La palabra poética permite el retorno de la provincia que vuelve convertida en morada onírica durante la noche y el sueño.
\end{abstract}

Palabras clave: intemperie, poesía, Jesús Urzagasti, Bolivia.

\section{THE WRITING OF JESÚS URZAGASTI: POETIC OF THE WIDE OPEN}

In this work, I analyze the poetry of the Bolivian writer Jesús Urzagasti as an "poetic of the wide open". His writing suppresses the sense of deprivation and abandonment of open-air life and builds a province, with a tree at its center, as a propitious place to "inhabit". Trees and horses representations show a territory left behind, which lives inside the subject. He succumbs constantly, to the memory of a happy past sheltered between the sky and the earth. The poetic word allows the return of the province that returns transformed into an oneiric dwelling during night and dream.

KEYWORDS: Outdoor, poetry, Jesús Urzagasti, Bolivia.

Recepción: 15/11/2017

Aprobación: 20/03/18 
Todo yo limito con el aire.

"Mapa" de Juan Cristóbal Mac Lean

\section{INTRODUCCIÓN}

El árbol de la tribu ([2004] 2012), de Jesús Urzagasti ${ }^{1}$, se inaugura con un corto texto donde el poeta se pregunta: “ ¿Hubo alguna vez un tiempo propicio para la poesía?" (11). Si bien no hay una respuesta certera, agrega que "el quehacer de los poetas resulta notorio donde quiera que el lector [...], preste atención al sigiloso tránsito de la utopía, que puede proceder de la casa de la mente o de la pasión de vivir a la intemperie" (11). Las imágenes vinculadas a lo espacial son recurrentes y definen ese "tiempo propicio para la poesía". La utopía, la casa y la intemperie se presentan como claves para ingresar al universo poético de nuestro autor. Me interesa detenerme en los significados que condensa este último término y mostrar los mecanismos que utiliza para subvertir sus sentidos e inscribir una poética del retorno, de la nostalgia y del amparo. Para esto, me detendré en el análisis de su escritura poética ${ }^{2}$ e incorporaré textos publicados de manera dispersa que no han sido trabajados ${ }^{3}$.

En el diccionario de la Real Academia Española, intemperie se define como "a cielo descubierto". Si nos remontamos a su etimología vemos que, el latín temperies-ei significa temperatura; con el prefijo in adquiere un sentido negativo. María Moliner (2007) la define como "ambiente atmosférico considerado como asiento de variaciones o inclemencias que obran sobre los lugares o cosas no abrigadas". Una serie de términos se vinculan a esta

Urzagasti nació en 1941 en el Gran Chaco boliviano. Desde muy pequeño comenzó a viajar con la finalidad de estudiar. Vivió en El Palmar, Villamontes, Tarija y Salta hasta que en 1961 llegó a la ciudad de La Paz para ingresar a la universidad. Estudió un año la carrera de geología y abandonó para dedicarse a la literatura y al periodismo. Trabajó en el suplemento Presencia literaria desde 1972 hasta 1998. Publicó siete novelas y cinco poemarios.

2 La obra poética de Urzagasti está compuesta por Yerubia (1978), La colina que da al mar azul (1993), El árbol de la tribu (2004), Frondas nocturnas (2008) y Senderos (2015obra póstuma).

La crítica literaria prestó especial atención a las novelas de Urzagasti en detrimento de su poesía. Blanca Wiethüchter (1983) y Eduardo Mitre (1988) son los únicos críticos que se focalizaron en sus textos poéticos. Si bien el tema de la intemperie puede analizarse en toda su escritura, tomaré los textos poéticos con la intención de hacer un aporte crítico sobre una zona de la escritura urzagastiana que aún no ha sido trabajada. 
palabra tales como expuesto, exterior, sin techo, entre otros. El sentido de desamparo está connotado en la idea de "inclemencia" y "no abrigado", es contrario a la noción de casa como refugio y espacio protector del sujeto. En la poesía urzagastiana, estos sentidos se anulan y se revierten. Se construye la intemperie como lugar de plenitud opuesto a habitaciones que asfixian al yo.

En la idea de intemperie se tensa una relación entre lo urbano y lo rural. Mientras que lo urbano aparece vinculado al caos, al desconcierto, a lo confuso, lo rural tiene que ver con una visión plena de la vida. El yo se ubica en un espacio intermedio que, por momentos, se desplaza a la ciudad y delimita un aquí y un allá. El allá siempre es la provincia; lugar observado desde lejos que mantiene cierta quietud ya que vive en el recuerdo. A su vez, es el sitio de donde emerge una visión de mundo que implica un posicionamiento frente al quehacer poético. En "Alguien mira pasar el agua" se construye ese espacio intermedio a partir de la imagen de un puente: "El hombre inventó el puente/ para cruzar de una orilla a otra [...]/ En cambio no está claro por qué alguien/ se apoya en la baranda/ y mira pasar las aguas rumbo al mar" (Urzagasti, Senderos 37). El sujeto no cruza, no atraviesa, sino que se detiene a medio camino lo que implica no poder fijar un espacio como propio. Desde un puente se asoman los extremos: uno de añoranza y otro de desarraigo; de un lado está el ciego caudal de la infancia, el "otrora sereno manantial" y los afluentes del cauce original; $y$, del otro, el océano de "brava corriente animal".

Desde esta posición "siente en su piel la púa del presente/ y las arterias bulliciosas de la vida/ invadiendo un mundo ausente/ entonces emerge entero de la marea/ y toca la ribera del silencio primordial" (Urzagasti, Senderos 37). Es decir que, al final del texto, se localiza en un presente incisivo y, desde allí, recobra el espacio lejano. El sujeto se convierte en un desterrado que recurre a un "lenguaje poderoso" el cual es "un río que corre abriendo inolvidables meandros" (Urzagasti, El árbol 7). La escritura poética se presenta como una manera de recuperar la intemperie que es la "casa natal" convertida en selva y en llanura. Gaston Bachelard, en La poética del espacio (1975), define la casa como lugar protector, rincón del mundo en donde se localiza la concha inicial que es germen de felicidad y albergue de recuerdos. Es allí donde está protegido el soñador y se guardan los secretos y lo íntimo. En la poesía urzagastiana, la casa no tiene paredes ni techos porque el sujeto no es ajeno a la tierra que le dio vida.

Hombre y naturaleza no son opuestos. Gravita la idea del mundo como totalidad en donde todos los elementos conviven armónicamente. Todo emerge de las profundidades del suelo, lugar del cual surge la vida; es allí donde se 
localiza la concha inicial y esto se inscribe en la interioridad del sujeto. La intemperie, vivida desde la distancia, no funciona como el lugar protector del recuerdo, sino que es el universo poético en donde se reconstruye el mundo dejado atrás. Las palabras protegen el espacio del pasado ya que fundan imágenes a través de las cuales el yo puede ser árbol y caballo, tocar el cielo e insertarse en la oscuridad del subsuelo.

El lugar natal se convierte en casa protectora y la escritura recupera su silencio. A su vez, lo interior, lo que late en el pecho, no permanece encerrado en un cuerpo porque éste asume diversas formas en un gesto de identificación con la naturaleza. La ausencia de límites corporales implica libertad. Ésta se opone a las habitaciones y cuevas del presente que acentúan la sensación de estar desposeído de la tierra. "Sin tener dónde cobijarnos, nos sentimos libres, plenos/ de resonancias, con la eternidad al alcance de las manos" (Urzagasti, El árbol 41). La intemperie aparece en forma de eco, no como sinónimo de una ausencia, sino como lo ido que pervive en el interior del soñador de palabras.

Si la intemperie es un símbolo que configura la visión del artista, la imagen del árbol se construye como una metáfora del quehacer poético. Urzagasti señala que su poesía publicada echó a andar confiada en "esa casual y benévola luz que los árboles transmiten hacia mundos de cuya hermosura nada sabemos. Sé que hacer del árbol un sinónimo de la poesía es una arbitrariedad, en mi caso inevitable" (Urzagasti, El árbol 13). Hecha esta afirmación, transcribe unos versos inéditos en los que dice: "Qué lejanos y olvidados esos campos donde fuimos felices/qué suave el idioma de los árboles que tejieron mis mandamientos./ Todavía sueño con un caballo en los linderos de un mundo amable/ y en la soledad heredada me descubro fiel a mi destino" (Urzagasti, El árbol 13). En estos versos aparecen imágenes que volverán de manera recurrente en la escritura poética: el espacio lejano como lugar feliz, la relación entre los árboles y el interior del sujeto, el sueño atravesado entre dos mundos, la soledad como condición del presente.

¿Y cuál es el destino de este sujeto? La respuesta la encontramos en el texto "La silla", publicado en la Revista Signo en 1987. Allí, Urzagasti, habla de su oficio de carpintero y de tres sillas que construyó a lo largo de su vida. Las descripciones en torno a la construcción de una silla están fuertemente ligadas a lo que implica la escritura poética: es, primero, "un ejercicio de devoción que comienza en las manos y se propala por el cuerpo sorprendido, poniendo en movimiento la totalidad de los recuerdos" (Urzagasti, La silla 131). La elección de la madera es importante solo para el profano ya que, el 
"auténtico artesano" toma materiales dispersos y los devuelve organizados bajo una forma reconocible. De la misma manera, los recuerdos de un tiempo ido se convierten en materia prima junto a las palabras. Respecto a estas últimas, el autor sostiene que "el código secreto de la poesía" se devela con el uso de palabras que, en otros tiempos, estuvieron en boca de todos y que en el presente resultan obsoletas. Esto no supone una pérdida de significado sino su "prístina recuperación" para convertirse en "llaves de mundos aparentemente clausurados" (Urzagasti, El árbol 10).

Al igual que las maderas dispersas, desechadas, las palabras en desuso recuperan su función en un presente donde no tienen cabida. El poeta busca los restos porque allí se consolida la forma de un mundo ausente, aunque no desaparecido. Al igual que las maderas dispersas sirven para dar forma a una silla, las palabras caducas posibilitan la verbalización de los recuerdos y, con ellos, la fundación de la imagen de la provincia dejada atrás: "Hacer una silla implica haber devorado con la mirada feliz vastos paisajes y maderas de valles, llanuras y montañas. Es también haber sucumbido a la seducción de aquellos árboles que crecen en silencio y se balancean al alba bajo el dictamen de una imagen incógnita, que nada tiene que ver con la congoja o la alegría, sino con lo innombrable" (Urzagasti, La silla 137).

A través de la mirada es que el sujeto se apropia del paisaje, lo devora, lo interioriza y lo mantiene en su cuerpo en forma de recuerdo feliz. La realidad objetiva se "desfamiliariza" y, como señala Alicia Genovese, la percepción teje la escritura poética y remite a una subjetividad (23). Los árboles abren mundos secretos y silenciosos porque esconden, en sus raíces, las imágenes incógnitas, el origen de la vida, el lenguaje cifrado de la naturaleza, el silencio necesario que implica un diálogo con las profundidades del suelo. El trabajo artesanal de construir una silla es un símil de la creación poética: ambas actividades son formas de hacer visible los materiales primigenios, aunque en ellos no pueda reproducirse su perfección; son solo lugares de reposo para "una persona que acaba de pasar por un túnel y se obstina en mirar sentada el paisaje soñado" (Urzagasti, La silla 133). No obstante, mirar es siempre una forma de volver $\mathrm{y}$, con el transcurrir del tiempo, la silla asumirá "otra vez la forma inicial que tuvo en épocas remotas" (Urzagasti, La silla 132).

Construir senderos de retorno al origen es el destino de este sujeto; multiplicar acciones que permitan recuperar ese pasado; volver a mirar el árbol enhiesto, en donde están las marcas de lo invariable y eterno. Dos universos se construyen: uno perfecto, invariable, perenne e invisible; el otro imperfecto, mutable, efímero y palpable. El sujeto se ocupa de construir el 
segundo para recordar la existencia del primero y esperar que el tiempo cíclico haga resurgir la autenticidad del mundo soñado. "La verdadera [realidad] se quedará en los extramuros de la vida" (Urzagasti, La silla 132). En este verso, la muerte no implica la desaparición sino el retorno al silencio inicial. Es decir, un volver a vivir sin las limitaciones que impone el mundo de los vivos. En este sentido, silla y poesía son modos de "aprender a morir", son fórmulas rituales para retornar al origen. Si la materia prima de la silla son las maderas de los árboles, la de la poesía es la experiencia de haber vivido a la intemperie, protegido bajo su sombra, en la "provincia de madera" (Urzagasti, Yerubia 18), y recuperar, a través del lenguaje, el idioma invisible de los árboles. De la misma manera que "un verdadero carpintero [...] continuará con la escritura cifrada de sus antepasados" (Urzagasti, La silla 132), la poesía toma el suave idioma de los árboles que son los antepasados del sujeto nacido de ellos.

\section{PROVINCIA VEGETAL}

Urzagasti cuenta, al referirse a sus lecturas, que una vez le preguntaron por su relación con la escritura de Rubén Darío, a lo que él contestó que no le incumbía la aventura del nicaragüense. Años después confiesa que el primer verso de "Lo fatal" fue "un hito en mi mundo en ciernes" (Urzagasti, El árbol 7). A este árbol, "apenas sensitivo", lo construye como símbolo de lo humano. "Lo primero que vi fueron árboles" dice Pablo Neruda y, junto a las metáforas de César Vallejo y de Rómulo Gómez, le dan forma al universo poético urzagastiano.

Los árboles funcionan como un símbolo que estructura la poesía de nuestro autor. Estos se ubican en el centro de la vida a la intemperie y unen lo más profundo de la tierra con la inmensidad del cielo. "La imagen de unos caballos galopando al alba, con la fugacidad propia del sueño, es un buen comienzo" (Urzagasti, El árbol 125), leemos en "La poesía como talismán". La palabra talismán tiene su origen en el griego $\tau \varepsilon ́ \lambda \varepsilon \sigma \mu \alpha$, sustantivo derivado de $\tau \varepsilon \lambda \dot{\varepsilon} \omega$ que significa "cumplir, efectuar, llevar a cabo" y que llegó a tener el significado de rito religioso. La poesía es un talismán porque enseña a 
vivir, lo que significa "aprender a morir" ${ }^{\text {, }}$ y convierte al hombre en un ser invulnerable señalándole los peligros del camino. Árboles y caballos se mencionan en esta conferencia como elementos mágicos surgidos del sueño. "Todos hemos visto caballos" afirma el autor, pero es a través del sueño que se les da vida, lo que deriva en la acción de crear un universo a partir de imágenes oníricas. Cuenta dos anécdotas en estas páginas: una de un brujo y otra de un mago. El primero había estado muchas veces en el monte; en uno de esos recorridos cayó un árbol sobre él y quedó atrapado durante un día y una noche. Este episodio se completa en "En la choza del morabito" el cual forma parte de Frondas nocturnas. Aquí el árbol se desploma sobre el yo lírico quien dialoga con un "hombre verde". Tras verse atrapado dice "el árbol que me aprieta la cintura será mi mujer" (Urzagasti, Frondas 40) y, posteriormente, sale una mujer cantando del árbol y lo lleva a la quebrada.

El yo y el hombre verde se convierten en una misma persona y la mujer le dice: "cuando el hombre verde se enamora del viento/ le pasa lo que te pasó [...]/ Mírame bien para que ya no se te olvide/ el embrujo que sintió el hombre verde" (Urzagasti, Frondas 40). En este caso, estamos frente a un sujeto "embrujado" por la naturaleza, el cual se transforma en "un árbol morabito/ crecido al centro de una choza" (Urzagasti, Frondas 41) y que, por medio de la magia, la mujer se queda a vivir en su interior. Es decir, es ahora árbol morabito, hombre verde y alberga en su cuerpo a la mujer. Es así como el poeta deviene brujo que llega a la ciudad sin abandonar el verdor del pasado.

El segundo episodio se refiere a un mago, salido de un sueño, quien "administraba el silencio que necesitan las palabras para respirar a sus anchas" (Urzagasti, El árbol 126). Una vez mató a un pájaro y el viento le devolvió la vida, otra fue comido por un león, pero logró salir por la "claraboya invisible de los leones" para ver la selva y la ciudad. También intentó poner un bozal al sujeto que narra y le abrió campo "en la fila de individuos que aguardaban su turno en la pira" (Urzagasti, El árbol 127). Frente a esto, el individuo toca una piedra que tiene en su bolsillo e imagina "lugares donde no los hay", hecho imposible ya que por todos lados hay "residuos de mundos fosforescentes" (Urzagasti, El árbol 127). El mago es el constructor del universo poético que recupera el silencio de las tierras profundas para convertirlo en palabras que

$4 \quad$ La idea de que es necesario aprender a vivir para aprender a morir, Urzagasti la toma del escritor paceño Jaime Saenz. 
le permitan recordar a sus antepasados, nombrar el mundo que se mantiene vivo en la piedra y que tiene una existencia continua y perdurable.

La poesía es esa piedra: un talismán que, por la acción del animal que enuncia, hace hablar al silencio dejado en la lejanía. El poeta, brujo y mago, puede ser árbol, estar habitado por caballos y construir un territorio onírico en donde pervive la provincia del pasado. La poesía se define como una "forma ritual para aproximarse a los orígenes, escritura cifrada del porvenir, marca evasiva de un presente efusivo" (Urzagasti, El árbol 125). Todo esto confluye en la acción de un sujeto insomne que, durante la oscuridad de la noche, retorna a su lugar de origen.

\section{1. Naturaleza salvaje}

En "El manuscrito de un caballo" confluyen una serie de ideas que aparecerán de manera reiterada en esta poesía. Entre ellas hay dos que considero centrales para pensar la noción de intemperie: una es la identificación del sujeto con el caballo y otra es el lugar de enunciación de dicho sujeto en el que se definen una serie de oposiciones: aquí-allá, pasado-presente, experiencia-razón, verdadero-falso, entre otras. Este texto está atravesado por la ausencia: allí no encontramos ni al manuscrito, ni al caballo. Lo que leemos es el testimonio de un yo que posee un manuscrito indescifrable y, con él, la memoria de una existencia. Lo que se tensa es, justamente, qué existencia reafirma el manuscrito: ¿la del caballo o la del poseedor del manuscrito?, ¿de qué manera influyen estos papeles en el sujeto que habla?, ¿no implica su posesión la posibilidad de decir algo, en este caso, la propia experiencia?

El texto puede dividirse en cuatro partes: en la primera se cuenta en qué circunstancias se conocieron hombre y caballo, la forma en que se obtiene el manuscrito y dónde está guardado, se describe la imposibilidad de traducirlo y de olvidarlo y se intenta hacer un perfil del caballo. La segunda es una carta, "cargada de ira" (Urzagasti, El manuscrito 162), dirigida a unos "Señores", los dueños del caballo. La tercera es otra carta, esta vez, dirigida al caballo y, la última, un corto fragmento que podría ser una parte del manuscrito, aunque no esté manifestado, pero también se puede interpretar como una escritura en donde confluyen las voces del animal y del sujeto que habla.

En la primera parte, el sujeto que habla se encuentra con el caballo, el cual le cuenta algo que nunca se menciona. El primero le pide que lo escriba en un papel para tener el "testimonio verdadero de un caballo" (Urzagasti, El manuscrito 157). Lo escrito se transforma en algo poderoso, capaz de conservar 
los sucesos del mundo, un espacio en donde mantener viva la memoria. No obstante, lo que sigue se ocupa de mostrar la falacia de esa afirmación. "Era yo algo que no entendía lo que las palabras ocultan o lo que el silencio rebela" y señala también la "transitoria condición" (Urzagasti, El manuscrito 157) de su organismo. Entre el antes y el ahora se da un proceso de cambio en el cual el manuscrito se apodera del sujeto que afirma haberse olvidado de sí mismo. En el presente, el caballo ya murió, pero los sentimientos hacia él se mantienen intactos. Es interesante observar que el narrador, al referirse a sí mismo, habla de "algo", de "organismo", es también un "huraño ser", voz sin nombre destinada a recordar en un sillón al lado de una ventana.

Se establece una relación entre la llanura del pasado y el encierro del presente. Entre estos tiempos y espacios hay una ruptura que se traduce en la pérdida de "lo que estaba destinado a mi persona" y que provenía del "cálido aire del verano" (Urzagasti, El manuscrito 158). El elemento que genera esta interrupción son los muros de la habitación donde se encuentra el sujeto. Estos muros funcionan como una línea que divide tiempos y espacios. En el pasado, se encontraba en medio de los árboles, envuelto en el aroma de la soledad que traía el verano, prisionero de lo que el cielo decía y la tierra rechazaba; en el presente, sostiene haberse "quedado del otro lado" (Urzagasti, El manuscrito 162), no ya envuelto por los árboles y la noche sino mirándolos desde una ventana. El manuscrito es el puente que conecta el aquí y el ahora con esa llanura oscura y distante.

En la carta destinada al caballo, el sujeto se autodefine como viajero y sostiene que esta condición ha "estropeado el manuscrito" (Urzagasti, El manuscrito 163) el cual se torna indescifrable. La imposibilidad de leer el mensaje tiene que ver con una escisión que se produce en el yo por haber dejado atrás el sitio en donde existía una comunicación con el cielo y la tierra. Ahora, el poder del texto reside, más que en su mensaje, en que aún sigue siendo el testimonio de un caballo. En el pasado, era un caballo que vivía a cielo descubierto y que ahora se transforma en este "algo" que no puede leer el manuscrito. Hay una serie de marcas textuales que permiten la identificación del yo y el caballo y que en la carta destinada al animal se hacen evidentes. "De ser imaginario tú, yo también lo soy" y agrega el narrador "temo dirigirme a un ser imaginario, condenado a vivir en mi memoria ya desierta de verdes praderas, que recorriste en tu juventud" (Urzagasti, El manuscrito 163). En esta carta se dirige a un "querido caballo mío" aún vivo que, por el paso del tiempo y de los viajes mencionados ha quedado guardado en la imaginación del que ahora escribe. 
Es necesario tener en cuenta que el texto iba a ser incluido en Tirinea. En ella se da un complejo juego entre sus protagonistas Fielkho y El Viejo, en el cual se tensa la relación vida y escritura. El proceso de identificación entre ambos se replica en "El manuscrito de un caballo": el animal encarna el pasado, la juventud y, con ello, la "vida vivida". El yo da cuenta de la distancia y la separación con ese pasado. En esto se diferencia de Tirinea ya que El Viejo, al final de la novela, debe ocuparse de la escritura y Fielkho se encarga de salir al mundo. En el texto que nos ocupa, el caballo solo existe en el papel, allí está inscrito su cuerpo, pero nada sabemos de su voz. El sujeto que habla también va desapareciendo y existe por el recuerdo del caballo y la posesión del manuscrito. Si en un pasado fue caballo, en el presente solo debe conservar el legado de ese pasado que pervive como palabra oculta y silencio de la letra impresa.

En la carta escrita al caballo hay una fuerte presencia del yo que se piensa a sí mismo, teniendo como punto de referencia el encuentro con el animal. El uso de verbos en primera persona, adverbios y pronombres personales sobresalen en esta carta y definen a un yo a partir de un tú: él se encuentra sentado en un sillón y comprueba que el mensaje "ha sido interferido"; señala el tiempo que pasó desde aquel encuentro y la imposibilidad de leer el papel que conserva; describe sus viajes que no hicieron más que dejarlo abandonado en la altura y amenazado por peligros; y, se pregunta lo mismo que supone quiere saber el caballo: ¿soy digno de tener el manuscrito? En esta interrogación se entrelazan otras que sirven para mostrar la posición del yo, quien ahora se define como "una pregunta que alguien le hizo a otro" (Urzagasti, El manuscrito 164). Para volver a tener una forma precisa es necesario que alguien obtenga una respuesta, por lo que le pide un nuevo mensaje al caballo. El sujeto que habla busca en lo recóndito de sí mismo a ese caballo desaparecido por la convicción de que con él volverán los aromas de la hierba y la llanura perdida.

En la última parte, el animal y la voz narradora son lo mismo y se presentan como un "caballo común, corriente y sordo" (Urzagasti, El manuscrito 164), en proceso de descomposición, encerrado dentro de sus propias fronteras y unido por un "melancólico cordón” al espacio del pasado. El manuscrito está atravesado por el dolor que genera la distancia y que imprime una fractura en el sujeto. El espacio del aquí y el ahora muestra a un ser quieto, contemplativo, atravesado por la pérdida de lo que fue. En el pasado, en cambio, se localiza la felicidad en un claro gesto de idealizar dicha época. Esta oposición lo que fue-lo que es se hace extensiva a toda la poesía urzagastiana y deriva en la 
construcción del texto poético como "morada onírica". El primer poemario construye ese lugar ideal al que denomina (igual que al libro) Yerubia. En el poema inicial, provincia y sujeto se funden: la primera habita en el interior del segundo, es decir, que se genera una interiorización de la tierra y los elementos que la constituyen.

Ojos dormidos en la indómita provincia de mi alma vieja ternura de la tierra reconocida por una canción piel dormida por el asombro de saberse viva y compañera de la injusta congoja que viaja desnuda en mi voz. Quieres emerger mojada por esta mirada cautiva mientras mi sombra se encamina hacia mejores climas y por acompañarte despierta a los ángeles remotos. (Urzagasti, Yerubia 2)

El alma del yo alberga a la "indómita provincia" y la voz a la "injusta congoja que viaja desnuda". Yerubia está personificada pero dormida en el interior del sujeto y busca emerger a través de su mirada. A su vez, los ojos permanecen cautivos de ese espacio que se desplaza junto a esta voz. La referencia a la provincia con el adjetivo "indómito" da cuenta de la fusión de los elementos vinculados al origen como un todo armónico. De la misma manera que la provincia habita en el interior del sujeto, en el poema "Yerubia" aparece como una sombra que lo acompaña y lo deja encarcelado en ese universo donde está el "origen del amor convertido en clima terrestre" (Urzagasti, Yerubia 5). Nuevamente, se mencionan desplazamientos y el que habla se construye como viajero que, a medida que avanza, siente la ausencia de Yerubia. La artificialidad del espacio urbano contrasta con lo natural. La provincia está ausente y es evocada y nombrada en momentos de angustia. Lo que vive en el interior del yo y que reclama esa presencia es la necesidad de alimento de un sujeto devenido caballo, el mismo que una vez fue "caballo en la llanura" (Urzagasti, Yerubia 5) y que ahora sólo tiene el recuerdo y el lenguaje.

En El árbol de la tribu hay una serie de poemas reunidos con el título "Bajo otro cielo" que continúan la idea presentada en "Yerubia" en torno a la relación sujeto-caballo y su vínculo con el espacio. Uno de ellos es "Jinete en imágenes". Allí, la oscuridad que se localiza debajo de la superficie terrestre, se vincula con la fundación del universo. De lo profundo de la tierra, donde no llega la luz solar emerge el universo y la luz. La oscuridad y el silencio adquieren un sentido vital y definen ese comienzo. 


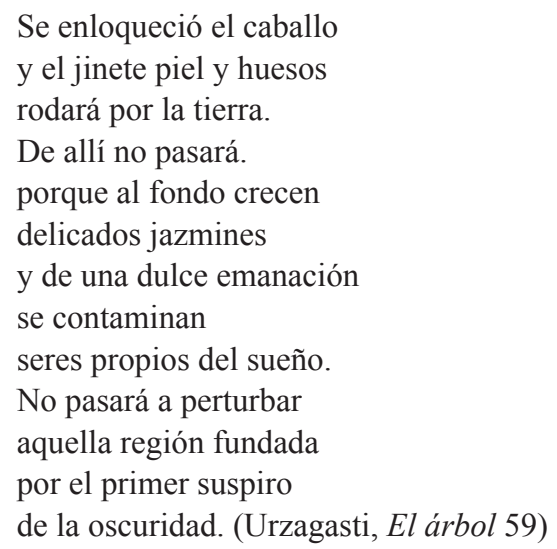

La imagen del jinete no forma parte del territorio surgido de la tierra, acentuando la idea de la provincia indómita construida en Yerubia. La naturaleza salvaje impide la intromisión de lo ajeno, de lo externo a la fundación de la vida. A su vez, el caballo se convierte en un protector que aleja el peligro. La localización del animal en el interior del sujeto, da cuenta de una escritura de lo íntimo, entendido como "lo más recóndito del yo, aquello que roza lo incomunicable, lo que se aviene con naturalidad al secreto" (Arfuch 102). Pero también nos introduce en el interior de la tierra y es allí donde toma forma el secreto y la imposibilidad de decir. El yo se transforma en el cuidador del silencio y la oscuridad y, de la misma manera que de la tierra surgió la vida, el poeta se erige como el fundador de un lenguaje que posibilita la pervivencia del espacio dejado atrás, el "territorio de la leyenda" (Urzagasti, El árbol 59). De la distancia surgen las palabras que encuentran en el sueño la posibilidad de mantener latente ese espacio.

Lo que permite el retorno son las palabras con las que se construye el universo poético, ya que ellas son llaves de universos clausurados. Dice el poeta: "No caminaron en vano los que un día partieron/ aquí están de vuelta con todas sus palabras/y con un silencio muy antiguo en la mirada" (Urzagasti, El árbol 107) y agrega: "Con unas cuantas palabras/ puedes tocar el silencio/ [...] van del clima del asombro/ a la tierra abrasada por el verano" (Urzagasti, Senderos 49). La imagen del sujeto viajero, que se distanciaba cada vez más del lugar ideal en Yerubia, recurre a las palabras como el elemento que abre el camino de regreso.

En una entrevista que le realizó Mauricio Souza a Urzagasti, menciona que su nomadismo terminó cuando se instaló en La Paz; antes de esto se había 
desplazado buscando el "centro inmóvil" de su país y señala: "acá me siento equidistante, acá creo aproximarme a ese centro inviolable que impulsó mi nomadismo" (Souza 4). Es necesario leer esto como la "construcción de una imagen de escritor" (Scarano 96) elaborada no solo en la escritura misma, sino también en los metatextos donde reflexiona sobre esas imágenes. Entre los versos citados y los dichos del autor se construye una distancia que el poema intenta suprimir. Frente a la quietud del sujeto que escribe, la palabra poética es el medio para retornar a los caminos y continuar un viaje continuo entre el aquí y el allá. Si el hombre "es el único animal que siente pasar el tiempo" (Urzagasti, El árbol 10), asimilar el sujeto poético al caballo genera que en su interior convivan espacios disímiles.

En 1986, Urzagasti publica un pequeño texto en la Revista Signo llamado "Animal antiguo"; posteriormente, lo incluye en El árbol de la tribu en una sección titulada "Quinto Cuaderno". Se inicia con la aserción "Soy un animal tan antiguo que mantengo el aire caduco de los seres inocentes" (Urzagasti, El árbol 121), en la que se explicita la fundación del sueño como morada mediada por la presencia del animal que habita en el interior del yo. En el comienzo, una serie de términos aluden a algo pasado y concluido: se autodenomina animal antiguo y habla del aire caduco. Pero, en el presente, este animal mantiene eso que quedó atrás y que no tiene cabida en el lugar desde donde enuncia. Esto genera que defina el espacio en el que se localiza $\mathrm{y}$, al hacerlo, se piensa a sí mismo como un "despojo" a quien ya nadie ve. Es decir, que se da un proceso de desaparición del sujeto. El espacio es un "universo amorfo que todo lo contiene sin dejarse influir por el contenido" (Urzagasti, El árbol 121). Esta relación entre el continente y lo contenido cobra sentido si retomamos la idea del caballo que habita en el interior del yo como un elemento que conecta lo cercano y lo lejano, ya que da cuenta de lo superfluo del espacio y, por lo tanto, de la imposibilidad de habitarlo.

Si leemos este poema en el marco de la escritura del autor, vemos una comparación entre ese espacio descrito como amorfo y la ciudad del presente en la que los elementos de la provincia no tienen cabida. Hay una serie de frases que muestran la imposibilidad de comunión entre animal y espacio: "las luces del presente amotinan este corazón emotivo que me sustenta", "perdido como estoy en la maleza de un paisaje luminoso", "qué podría ocurrirme en esta soledad, si soy el inalterable testigo de lo putrefacto y perecedero" (Urzagasti, El árbol 121). La luz que define el aquí tiene connotaciones negativas y se opone a la oscuridad de la noche: lo primero tiene que ver con lo vacío, con la soledad, con el fin de la vida; lo segundo, en cambio, está 
vinculado a lo profundo y a la niñez. Y es justamente en esas profundidades del ser, donde encuentra el sustento que le permite sobrevivir; es el corazón turbado el que mantiene el aire caduco. La idea de seres inocentes y de lo inalterable reafirma la construcción de la provincia como un locus amoenus, paraíso perdido en donde se sitúa la felicidad del origen.

Si el pasado aparece como algo perdido y el presente está marcado por lo negativo, es necesario construir un lugar en donde lo que ya fue se mantenga intacto. Al final del texto, el yo afirma vivir en la "gran casa solar [...] aunque en la profundidad del sueño me encuentre, la morada que gobierno aunque en la senda de la noche me despierte" (Urzagasti, El árbol 121). Sueño, noche, oscuridad y profundidad son los elementos que le dan forma a esa morada y que remiten a la tierra y al origen de la vida presentados en otros poemas. Todos ellos, a su vez, son un camino de retorno que se interrumpe cuando la noche termina y aparece la luz del sol.

\subsection{RAMAS, FOLLAJES Y RAÍCES}

"Inolvidables arboledas", "A una provincia construida con árboles", "Ramaje encendido" son algunos de los títulos de poemas, a los que se suman los libros Frondas nocturnas y El árbol de la tribu, que colocan las imágenes de árboles en el centro de esta poética. Entre la copa y las raíces se conecta el arriba y el abajo, el cielo y las profundidades de la tierra y, a su vez, estos se localizan en la superficie terrestre. La imagen del árbol involucra todos los espacios implicados en la vida del hombre, lo que será explotado en la escritura de Urzagasti en dos direcciones principales: la primera posiciona a los árboles como un objeto externo al sujeto, lo que sirve para construir la imagen de la provincia y la vida a la intemperie; $y$, la segunda entrama una relación entre el yo y los árboles.

En la construcción de la provincia a partir de los árboles, toma forma la figura del yo como un viajero atravesado por el desarraigo. Mientras ellos están enclavados en el suelo, el sujeto dará cuenta de su destierro. La provincia dejada atrás está "construida con árboles" y el yo poético afirma "Miro un mapa y te siento cerca" (Urzagasti, El árbol 17), acentuando la idea de la lejanía. La mirada y los sentimientos son las maneras de retornar. La imagen que se construye de la provincia está mediada por el recuerdo. Ella está "dulcemente amarrada a las lluvias", es "compañera cálida y enérgica", es "elemental”. Todas estas formas de nombrarla acentúan su carácter idílico 
y su relación con el yo y $^{5}$ La provincia se desplaza al interior del sujeto y se construye en una imagen que protege a la voz que le da vida. En el centro de este universo están los árboles, ellos lo abarcan y lo conocen; en ellos confluyen todos los elementos naturales y representan la vida a la intemperie en la que el yo habita plenamente. A la sombra de un árbol se disuelven las contradicciones que colocaron al sujeto en un lugar intermedio; naturaleza y hombre se corresponden y el yo puede afirmar su existencia.

\author{
En la hermosa noche \\ debajo de un árbol \\ al fin sabré quién soy. \\ [...] Debajo de un árbol \\ solo con mi sombra \\ en silencio estoy yo. \\ [...] La tierra se enciende \\ debajo de un árbol \\ al saber quién soy. \\ Luna que alumbras \\ a vivos y muertos \\ debajo de un árbol \\ siempre estaré yo. (Urzagasti, Senderos 73)
}

En cuanto a la relación que se establece entre el yo lírico y los árboles se da un proceso de identificación en donde el elemento natural no se encuentra en el interior del sujeto como ocurría con el caballo, sino que la voz poética deviene árbol. El texto donde más claramente se ve esta síntesis es "Matinal" (leído a la luz de los versos de Alejandra Pizarnik en "Sólo un nombre") el cual forma parte de La colina que da al mar azul.

$5 \quad$ Es necesario destacar que esa provincia referida siempre aparece distante y, si bien podría pensarse en relación a la tierra natal del autor, las referencias y la mención directa a ese espacio son muy pocas. Esta lectura no pretende vincular la figura del sujeto que dice yo en los poemas con la figura autoral sino que parto de la idea de que "el yo del poema es siempre un sujeto retórico y ficcional" (Scarano 2007, 84). Esa tierra distante remite, necesariamente, a la experiencia del sujeto histórico que escribe, pero es una construcción verbalizada de su memoria, es una experiencia "trabajada" (Scarano 2007, 84).

6 "alejandra alejandra/debajo estoy yo/alejandra" (Pizarnik 2005, 65). 


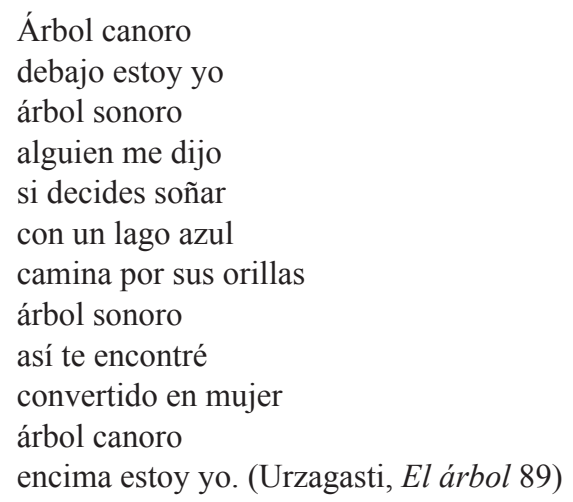

El encuentro entre voz y nombre en los versos de la poeta argentina, se replica en los de Urzagasti, pero el nombre es reemplazado por la imagen del árbol cantor. La posición del sujeto que fluye entre el arriba y el abajo da cuenta de la forma en que ingresan los diferentes elementos al universo onírico. Para soñar, primero es necesario experimentar, ver y sentir; es así como las imágenes se guardan en el interior del soñador que transforma en palabras la experiencia del pasado.

La relación voz-árbol se sustancia por la experiencia de haber habitado la provincia: "Desde la copa de un árbol/tuve la certeza de ser Uno/en lo más remoto del mundo" (Urzagasti, El árbol 30). En esta cita, lo lejano y lo ya ido definen al yo que logra la unicidad en la intemperie, en los confines del país donde el corazón niño estaba formado por madera y agua (Urzagasti, $E l$ árbol 45), la sangre era un follaje (Urzagasti, El árbol 100) y se alimentaba de raíces (Urzagasti, El árbol 106). Palabra e imagen se unen para recuperar lo vivido en donde el yo era una "certeza sin palabras" (Urzagasti, El árbol 66).

En "Matinal”, el árbol está transformado en palabra poética y el sujeto que lo nombra lo abarca de la misma manera que aquél entrelaza todos los planos del universo. El yo se instala entre las tierras bajas de la llanura y las tierras altas andinas y todo cobra vida por las imágenes que construye como forma de recuperar el lugar natal. En el libro que reúne la poesía de Urzagasti hay un poema que lleva su mismo nombre "El árbol de la tribu". Éste forma parte de La colina que da al mar azul, pero allí se tituló "Árbol nocturno". Entre ese poema y la publicación de Frondas nocturnas pasaron quince años y la cercanía entre ambos títulos es evidente. En este último texto leemos "Inolvidables arboledas" el cual tiene una fuerte vinculación con el mencionado anteriormente. 
El sujeto se define como un árbol: en uno es "un árbol que sale de una habitación/a buscar el ancho cielo" (Urzagasti, El árbol 71); en el otro, asevera "soy un frondoso árbol" (Urzagasti, Frondas 127). La presencia de la mirada es indispensable para realizar estas afirmaciones; mirar implica fundar imágenes. Para Maurice Blanchot "ver supone la distancia", pero es una separación que implica un encuentro y genera la imagen en ese "contacto a la distancia” (28). De la pasión por la imagen surge la fascinación que es

La mirada de la soledad, la mirada de lo incesante y de lo interminable donde la ceguera todavía es visión, visión que ya no es posibilidad de ver sino imposibilidad de no ver, la imposibilidad que se hace ver, que preserva-siempre y siempre-en una visión que no termina: mirada muerta, mirada convertida en el fantasma de una visión eterna. (Blanchot 29)

Nombrar es la acción de hacer presente lo ausente, de construir la provincia eterna, de imaginar ríos que no cesan, un árbol solitario a la orilla del camino, pájaros y senderos, el galope de un caballo. Todos estos elementos, erigidos en imágenes, forman parte de una realidad interior desde donde se construyen las certezas. La lejanía produce la fascinación y es el destierro donde el sujeto, absorbido por la nostalgia, crea un paisaje íntimo como un modo de mantener viva la memoria del pasado.

En los valles sureños de mi juventud vi una arboleda de sauces y molles meneándose sobre la tierra pelada en una danza sin cabos sueltos de cuya hermosura disfrutaba el viento. Acodado en la única ventana sin luz ahora quiero hablar de las frondas que se asoman a mi vida como sombras y ecos de inquietudes pasadas. (Urzagasti, Frondas 127)

En la quietud del ahora se recupera lo visto en la juventud y la palabra es el medio a través del que nombra el idioma de los árboles que es silencio y oscuridad. En el presente, "aquel hombre [...] recuerda un poema/un modo de ver” (Urzagasti, El árbol 71). El árbol nocturno no es más que el sujeto que habla en la noche "y calla al amanecer" (Urzagasti, El árbol 71), el "animal letrado/ (que) se alimenta de recuerdos" (Urzagasti, Frondas 128), 
el yo que mira desde la distancia, lo que implica mirar en su interior. Si el árbol era pensado como dador de vida, conectado a las profundidades de la tierra, el sujeto que habla es también una imagen surgida de la mirada de un árbol: "Hace mucho tiempo un árbol sin edad/me dijo soy tu padre y soy tu madre/y me dejó en la punta de un cerro./ Me deslumbró después el árbol/ que me miró y siguió su camino" (Urzagasti, Frondas 128).

\section{HABITACIONES, CASAS Y CIUDADES ${ }^{7}$}

"La casa donde yo nací se la llevó el viento/ el día que salí a rodar el mundo" (Urzagasti, Frondas 33) es la imagen con la que se inaugura el poema "Dulce y lejano hogar" y que instala dos metáforas a partir de las cuales se representan habitaciones y ciudades: la primera es el hogar dejado atrás, ubicado en el pasado el cual instala la nostalgia como el tono preponderante de la poética urzagastiana. La segunda es la imagen del caminante que define los lugares de enunciación del yo poético.

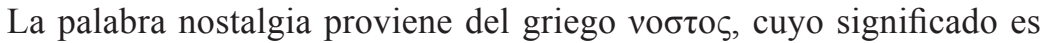
"vuelta al hogar" y de $\alpha \lambda \gamma o \varsigma$ que se traduce como "dolor". Para María Moliner es la "tristeza por estar ausente de la patria o del hogar". Cristina Elgue-Martini (2008) rastrea sus usos a lo largo de la historia y destaca que, durante el siglo XIX, se convirtió en un topos literario que designaba un lugar y un tiempo irremediablemente perdidos. Si bien, la palabra tuvo otros derroteros me interesa retomar esta concepción de la nostalgia vinculada al espacio para detenerme no en la construcción de ese espacio perdido, sino en la experiencia del presente que implica esa pérdida. La partida del lugar natal transforma al sujeto en un "intruso" en el mundo, un desterrado en el sentido de "quitar la tierra a las raíces" (DRAE).

El hogar, la casa natal construida con árboles, quedó atrás, lo que se traduce en la vivencia del presente a partir de la lejanía. "Nos fundaron en la lejanía/ y nos dejaron en el presente/ nómadas tendiendo puentes para devastar/ las

7 A lo largo de la obra de Urzagasti, el tema de casas, habitaciones y ciudades es recurrente. He indagado en profundidad el tratamiento de dicha temática en sus novelas. Ver "En el país del silencio. Novela desmembrada", publicada en el № 9 de la Revista Recial; "El espacio troceado", publicado en el N ${ }^{\circ} 2^{\circ}$ de la Revista Pilquen; y "La memoria incesante", el cual saldrá en el próximo número de la Revista Revell. 
ciudades levantadas por los sedentarios" (Urzagasti, El árbol 95) afirma el sujeto devenido en "guardián verde". Nuevamente, lo lejano se localiza en el pasado y, desde el lugar de enunciación se quieren construir maneras de proteger y conservar la vida surgida de la tierra.

En relación con los nómadas y sedentarios, dice el narrador de la novela Los tejedores de la noche que los primeros construyen chozas pasajeras para descansar de las andanzas, mientras que los segundos se resguardan en una casa para protegerse de las inclemencias del tiempo. La ciudad levantada por los sedentarios funciona como esa casa ajena a la vida a la intemperie y la artificialidad rompe los vínculos con el suelo. "La ciudad prescinde de la naturaleza. Sus ecos/ son otros. Su resina secreta es artificial. [...]/ Es aquí donde interviene el esplendor metálico/ de la geología profana. [...]" (Urzagasti, Frondas 39).

La ciudad profana está construida por elementos espurios que tienen la marca de lo pasajero y lo mutable. Los sentidos se invierten en el mundo urbano: el cielo protector y cautivante de la provincia ahora es indiferente (Urzagasti, Senderos 55), el silencio se transforma en algo que intranquiliza (Urzagasti, El árbol 26), él árbol de la ciudad es intocable (Urzagasti, Frondas 39). Frente a esto, el yo poético le pide al monte, en un idioma secreto, "no me abandones en este desierto de ilustres palmeras" (Urzagasti, El árbol 27) y mira el cielo que lo conecta con la tierra del origen para que oriente "el rumbo de mi sangre" (Urzagasti, El árbol 27).

Para el sujeto la ciudad es "un país desconocido" (Urzagasti, El árbol 35) que acentúa la idea de destierro. Esto genera la reclusión del yo en una habitación en donde están inscriptas las marcas del desamparo. El recinto se menciona en diversos poemas de Urzagasti, aunque lo que sobresalen son las sensaciones del yo frente a un mundo ajeno que pide, con profunda tristeza, el amparo de la tierra, es decir, que el espacio está construido a partir del sujeto. Es reducida y amenaza con estrecharse cada vez más, generando una sensación de asfixia, ya que no ingresa el aire de la vida a cielo descubierto. Todo allí está en sombras y funciona como cárcel donde el sujeto quedó encerrado "sin poder abandonar la ciudad" (Urzagasti, Frondas 66).

A la casa no ingresa ningún objeto, solo se mencionan ventanas como puentes entre el aquí y el allá. Su función es la de "conectar a la distancia", en términos de Blanchot, con lo que se sustancia la imagen del yo como un observador. Esto tiene una serie de implicancias de las que me interesa señalar tres: la ventana es solo atravesada por la mirada, a diferencia de las puertas que permiten el traspaso de los cuerpos; el ojo que mira por estas ventanas 
es un "ojo ciego", lo que genera que el universo que se abre no tiene que ver con un mundo objetivo, sino con lo subjetivo que habita en el interior del que observa; y, esta mirada, que convierte al mundo en imagen, hace surgir la morada onírica en oposición a la casa real.

La ventana es el elemento que conecta al sujeto con lo lejano, pero también es una barrera que impide al cuerpo habitar el espacio del presente. Solo la mirada conecta y, el mundo que se presenta ante los ojos está atravesado por los sentimientos del yo: "Lejano el árbol/ distante la brisa/ cabizbajo el caballo/ sigilosa el agua del alba/ en la hierba lacia respira otra primavera" (Urzagasti, El árbol 60). La posibilidad de mirar surge por el ingreso del aire, a través de la ventana, que llega a la habitación e incita a recordar ese paisaje natal y genera calma en el sujeto. El mundo permanece ensombrecido y contrasta con "una ventana iluminada" (Urzagasti, Frondas 65), por la que el yo observa el cielo para "presentir las noches serenas/ las praderas del tiempo y su viento sigiloso" (Urzagasti, El árbol 46).

La ventana abierta e iluminada es una manera de recordar un espacio. Esto produce una escisión en el universo del yo en dos direcciones: por un lado, el ojo es un fragmento de un cuerpo que ya no habita un sitio, sino que lo contempla desde la distancia; por otro, la armonía del mundo de antaño se quebranta, ya que este observador dejó de formar parte del paisaje. El universo construido a través de la mirada define, más que un lugar del pasado, la condición del presente, marcada por el dolor de la ausencia. Los primeros versos de "El guardián verde" dan cuenta de los diferentes elementos del universo que el yo conserva y resguarda. La mención al hombre se distancia de ellos y, si tenemos en cuenta que es uno de los pocos poemas en que se lo nombra, emerge como algo ajeno a la provincia.

De la selva los parques del silencio la luz de los caminos el desierto de las estrellas la noche de la distancia el agua de los arenales el viento de las lluvias el tiempo de los días la comarca de la hermosura el trino del recuerdo la palabra del ayer la canción del jinete el caballo del aroma la mujer del infinito el polen del verano el cielo del amor la tierra del amarillo el otoño del invierno muda nostalgia del sonido el crepúsculo de lo imprevisto el hombre. (Urzagasti, $E l$ árbol 95) 
Estos versos pueden dividirse en tres partes: la primera incluye luz, noche, viento, comarca, palabra, caballo y polen. Todos surgen de la tierra mencionada en el verso siguiente, vinculada al verano, el cielo del amor. Esta estación del año aparece en la escritura de Urzagasti como el "suceso central" de la provincia $y$, en el texto en cuestión se relaciona con el cielo y la tierra ${ }^{8}$, es decir, que todos los otros elementos están contenidos aquí excepto la "muda nostalgia" y el "hombre". Esta división está marcada por la estación de donde emerge la nostalgia: el "otoño del invierno", como lo opuesto al verano, es la marca de la distancia; la mudez también se aleja de lo surgido de la tierra ya que en ella reina el silencio. Lo mismo sucede con el sonido que implica la finalización de lo esperado y lo conocido. Hombre y sonido están fundados en la lejanía e implican, por lo tanto, la ruptura de la armonía que surge y habita la tierra.

Friedrich Bollnow observa, en unos poemas de Rilke, que el efecto separador de la ventana "pone de relieve un fragmento del mundo destinado a nosotros" (149), el cual se convierte en una imagen intemporal e ideal. En la observación contemplativa de la ventana se revela un secreto insondable; el hombre queda absorbido en la contemplación del paisaje y "sustraído a la presión inmediata de la realidad" (150). El ojo mira sin ver y, en este gesto, se produce un desplazamiento hacia una mirada interior y la ventana se transforma en puerta a universos invisibles. Esta mirada, en la poesía de Urzagasti, es la del "ojo ciego" y, en este caso, tiene dos sentidos equivalentes entre sí: es ciego porque mira en el interior del yo y también porque mira en la oscuridad del origen, en lo profundo de la tierra.

Mi ojo, que nació asombrado, yace en su lecho inmemorial, siempre atento al gentil paso de las nubes, al perfume que viene del fondo de las cosas, como si se despidiera de lo transitorio y buscara el caro estallido del silencio. [...] De mi organismo difunto vuelven a la vida los árboles que te trajeron como una promesa hasta mi pecho. (Urzagasti, El árbol 114)

El ojo que observó la armonía del universo reposa en la tumba, y su muerte implica no ver el mundo transitorio, la ciudad que se asoma por la ventana.

8 La imagen de "guardián verde" hace referencia a los árboles, pero también puede ser el sujeto devenido árbol. Entre el cielo y la tierra están los árboles. A su vez, en la relación con el verano el árbol es dador de sombra protectora. 
"La muerte me redime" (Urzagasti, El árbol 58), dice el yo poético, lo que puede leerse, en este texto, como una liberación, un volver a la tierra, ver el paso de las nubes, sentir el perfume del fondo de las cosas, escuchar el silencio del origen. Con el cuerpo difunto resucitan los árboles, pero no como realidad objetiva sino como algo que habita en el interior del sujeto.

Los primeros versos de "La ventana" muestran esta construcción interior del espacio: "El viento de la noche entra por la ventana/ y un relámpago ilumina la habitación/ para dejarla temblando en la oscuridad" (Urzagasti, Senderos 81). El universo tiembla y habita en el interior del sujeto. Esta idea se refuerza en unos versos donde un caballo, identificado con el yo, dice: "cuando cierro los ojos/ el universo tiembla conmigo" (Urzagasti, Frondas 128). La imagen se reitera en un poema en prosa que establece las diferencias y semejanzas entre hombre y caballo. De este último dice: "Al atardecer retorna al lugar que su exigente ser considera adecuado para perdurar como puro deseo. Finalmente, duerme mientras el universo tiembla en su cuerpo" (Urzagasti, El árbol 112). Me referí en páginas anteriores al caballo como un animal que habita en el sujeto y conecta lo cercano y lo lejano. En los versos citados, esta propuesta se refuerza y la luz se transforma en imagen que llega con los vientos lejanos para fundar el paisaje interior que retorna en la oscuridad de la noche. Abrir las ventanas y cerrar los ojos son medios para fundar "el paisaje divino en mi corazón" (Urzagasti, El árbol 113).

Toma forma la morada interior llamada "madriguera de bejucos" (Urzagasti, El árbol 46) y cuya única lámpara es la oscuridad. La distancia, entonces, produce un quiebre en el yo, quien necesita de la oscuridad para recuperar el paisaje del pasado. Antes era Uno en la provincia, bajo el sol de la ciudad, es "uno del montón/ emergiendo del hormiguero/ rumbo a una existencia sin salida" (Urzagasti, Senderos 81). Hay un yo diurno y uno nocturno y, esta escisión, se hace extensiva al espacio: hay uno real y otro ideal. La oposición entre el espacio del pasado y su reflejo en el presente se complejiza para crear un tercer espacio que puede ser habitado plenamente.

\subsection{LA CASA DEL LENGUAJE}

En La tierra y las ensoñaciones del reposo (2006), Gaston Bachelard habla de la casa del recuerdo, construida con imágenes que genera la anulación de la casa real, en su lugar el hombre habita una imagen. El sujeto que recuerda es un soñador encerrado en sí mismo, un rincón sombrío. No obstante, hace una distinción entre casa natal (la casa del recuerdo) y la casa onírica: sostiene 
que la primera está "construida sobre la cripta" de la segunda y agrega "en la cripta está la raíz, la pertenencia, la profundidad, la inmersión de los sueños" (117). En la casa oníricamente completa "se puede vivir en toda su variedad las ensoñaciones de intimidad" (121). La casa onírica se impone en la poética urzagastiana y transforma la habitación "real" donde solo había nostalgia en un albergue que reproduce la vida a la intemperie. En Senderos, nos encontramos con un poema titulado "Mi habitación" en el que se hace esta construcción. Su título da cuenta de algo propio y en ella aparecen todos los elementos que le daban forma al paisaje natal.

Mi habitación es lluviosa como las tierras del sur
y en las noches de luna
con sus altos y sombríos árboles
parece una estancia
salida de un sueño anterior al tiempo.
De sus paredes cuelgan bejucos fosforescentes
sombreros llicas espuelas bridas yesqueros
y en sus estanterías libros antiguos
y viejas herramientas
hablan de la precisión de un oficio
que levanta vuelo desde las manos
hacia un inefable idioma desconocido. (Urzagasti, Senderos 89)

En los primeros versos se muestra un espacio sin techo donde ingresan las lluvias, la luz de la luna y crecen los altos árboles. Las paredes son tomadas por bejucos pero también allí conviven elementos de mundos disímiles; uno remite a un hombre rural, otro a los libros y a la cultura letrada y el último a herramientas de algún oficio manual. Todos dan cuenta del retorno al lenguaje original y salen de un sueño atravesado por lo intemporal y lo inefable. Urzagasti entendió la poesía "como un estallido que provoca el organismo humano para recuperar la relación armoniosa con el universo" (Hipótesis 145). El estallido, entendido como el nacimiento de la palabra poética, funda el universo onírico en donde se concreta la armonía, hecho posible porque "los seres que nos habitan en sueños ignoran que son evanescentes. Desordenan la casa, se comprometen con la música de lo ido, olfatean el polen de la estación dorada, iluminan las penumbras de la memoria, se meten en honduras y aparecen en alturas, a salvo del tiempo fatal" (Urzagasti, El árbol 8). Es decir, rompen con las limitaciones de la casa real, derriban paredes y se trasladan en el tiempo y en el espacio; aparecen y desaparecen, se esfuman y habitan un "tiempo subalterno" (Urzagasti, El árbol 8). 
La morada onírica está construida por el sujeto, a través de la palabra, como medio propicio para habitar. La esencia del construir, según Heidegger, es el "dejar-habitar" y para recuperar los sentidos de ese habitar es necesario vincularlo además con el "pensar". El filósofo se refiere a una "crisis del habitar" y dice que "tan pronto como el hombre medita la falta de hogar, ésta no es ya una miseria. Es, meditada rectamente y mantenida adecuadamente, el único llamado que invita a los mortales a habitar" (Heidegger 11). Concluye afirmando que para llevar el habitar a la plenitud de su esencia, los hombres, tienen que construir a partir del habitar y pensar para el habitar (Heidegger 11).

Esta aseveración se sustenta en la fe en la razón y en el pensamiento como medios para aproximarse a la cuestión del "ser hombre". En la escritura de Urzagasti, hemos observado una crisis, producto de la lejanía y de la ausencia de hogar, pero aquí no se apela a la razón sino a la vida íntima de donde emergen sentimientos y maneras de "estar en el mundo". El pensar debe ser reemplazado por el soñar entendido como una forma que "nos libera de la opresión de las formas, y que nos devuelve a la sustancia y a la vida de nuestro propio elemento" (Bachelard, El aire 39). Esta concepción del sueño en Bachelard tiene que ver con el vuelo que aparece en la vida nocturna y se transforma en ensoñación en la vida diurna, generando que el sujeto que escribe esté atravesado por las imágenes de profundidad. Mediadas por el lenguaje, construyen su propio universo, el cual "conserva siempre las grandes leyes de lo imaginario" (Bachelard, El aire 307).

En "Tu imagen" el yo se refiere a una mujer. El sujeto lírico comienza diciendo "Eres como te imaginé" (Urzagasti, El árbol 76) y concluye con una pregunta que se hace a sí mismo: “¿Describes una imagen o viajas hacia el árbol/ que me define en el paisaje?” (Urzagasti, El árbol 76). Es decir, que el universo construido a través de las palabras tiene la marca de lo dinámico. Éstas dejan al descubierto la oposición entre percepción e imaginación. No dependen de la relación directa con el "mundo real", lo que generaría estatismo en la imagen, sino que son móviles porque "viven la vida del lenguaje vivo" (Bachelard, El aire 11) y se desprenden de la realidad para surgir de la experiencia interior del sujeto.

El yo, en el poema de Urzagasti, necesita del viaje para construir imágenes, lo que implica introducirse en su propio interior y recuperar las creaciones oníricas en donde afirma su existencia. Un corto poema en prosa muestra el proceso de construcción de la imagen: "De tanto querer ver una mariposa en las horas menos apropiadas logré imaginar una. De modo que ahora la reconozco cada vez que la imagino. Lo cual no es nada malo. Pero tampoco 
es bueno, porque me he vuelto ciego" (Urzagasti, El árbol 113). La ausencia del objeto que desea ver produce que la tenga que imaginar. La mariposa cobra vida y permanece en ese espacio construido por el soñador. Habla de "horas menos apropiadas" y de ceguera, ambas protegen sus construcciones: el sueño del poeta encuentra en la noche y en la oscuridad su resguardo a lo que se le suma el silencio guardado en la voz que "resume el silencio de [1] [su] paisaje natal" (Urzagasti, El árbol 75).

En la oscuridad y en el silencio que habita el soñador se reproducen los sentidos de la vida a la intemperie. Dos idiomas aparecen referidos: uno habitual y "otros/ habitados por árboles y fantasmas/ allí el viento es pleno viento/ canción de la vida a medianoche" (Urzagasti, El árbol 74). Aquí están el mundo diurno, el del lenguaje cotidiano y el mundo nocturno; el momento del viaje hacia la casa onírica vivida como espacio propicio para habitar porque genera el retorno, desde la distancia, a la provincia que habita en el corazón del yo. Este retorno es construido a través de las palabras.

No caminaron en vano los que un día partieron aquí están de vueltas con todas sus palabras y con un silencio muy antiguo en la mirada.

Pensé que nos íbamos a extraviar en el gran mundo creí que todo se esfumaría en el ruido de los días y que la noche nos esperaría con otra fachada de modo que sufrí sin anticiparme al milagro de las pérdidas. despojarse es la ley quedar sin nada al término de la jornada erguirse en la oscuridad sin alas.

Pasos otrora sombríos buscan las huellas de una existencia intocable.

$\mathrm{Al}$ cabo de los años todo termina siendo un follaje.

El amarillo maizal se balancea en el recuerdo el sendero tiene un trecho que no lo cruza nadie salvo los que retornan con la luz prometida. (Urzagasti, El árbol 107)

El retorno necesita de las palabras, para que el espacio lejano perviva y no desaparezca. "Ruido" y "días" se relacionan con el desamparo y se oponen a la oscuridad y el silencio. No hay pérdidas en la casa del poeta quien se despoja de este mundo para volver a ser árbol y resurgir de lo profundo de la tierra. Las palabras construyen la morada onírica para que del interior del 
sujeto emerja un mundo, convertido en follaje, en el que pueda repatriarse, volver a habitar esa región intransferible. Donde había desamparo ahora hay amparo; donde había destierro hay un retorno a la tierra que devuelve la vida a cielo descubierto.

\section{CONCLUSIONES}

La intemperie es un elemento definitorio de la escritura poética de Urzagasti y se relaciona con ensayos y conferencias publicadas de manera dispersa por el autor. En este trabajo abordé los cinco poemarios y también "La poesía como talismán", "La silla" y "El manuscrito de un caballo". El aquí y el allá, el antes y el ahora delimitan el presente, teñido de nostalgia, desde donde habla el yo poético. La vida a cielo descubierto se localiza en el pasado y los árboles aparecen como metáfora del amparo y la protección, opuestos a las habitaciones del presente que asfixian al sujeto. La escritura poética funda lo que denominé "morada onírica" donde las imágenes que habitan en el interior del yo son los cimientos de un espacio protector que posibilita el retorno a ese tiempo dejado atrás. En la noción de intemperie se produce un encuentro de sentidos contrapuestos de donde surgen nuevos significados a partir de un proceso de búsquedas. La escritura de Urzagasti se erige como el espacio de esas búsquedas en donde nada está dado y donde todo puede significar algo más y romper, así, con la fijeza de un universo construido por imposiciones y saqueos.

\section{BIBLIOGRAFÍA}

Arfuch, Leonor. El espacio biográfico. Dilemas de la subjetividad contemporánea. Buenos Aires: FCE, 2010.

Bachelard, Gastón. El aire y los sueños. México: FCE, 1958.

La poética del espacio. México: FCE, 1975.

La tierra y las ensoñaciones del reposo. México: FCE, 2006.

Blanchot, Maurice. El espacio literario. Madrid: Editorial Nacional, 2002.

Bollnow, O. Friedrich. Hombre y espacio. Barcelona: Labor, 1969.

Elgue-Martini, Cristina. "Melancolía y nostalgia: algunas reflexiones teóricas". Revista de culturas y literaturas comparadas. Vol. 2 (2008): 11-20. 
Genovese, Alicia. Leer poesía. Lo leve, lo grave, lo opaco.Buenos Aires: FCE,2016.

Heidegger, Martin. "Construir, habitar, pensar" (s/d), 1951.

Hipótesis (Miembros del Comité Editorial de). "En el día y la noche: Diálogo con Jesús Urzagasti”. Revista Hipótesis No 3, Mayo (1977): 145-156.

Pizarnik, Alejandra. Poesía completa. Buenos Aires: Lumen, 2005.

Scarano, Laura. Palabras en el cuerpo. Buenos Aires: Biblos, 2007.

Souza, Mauricio. “Jesús Urzagasti: El silencio necesario. Entrevista”. Revista El Zorro Antonio $\mathrm{N}^{\circ}$ 5. UMSA, La Paz (1988). Pág. 14-15.

Urzagasti, Jesús. Yerubia. La Paz: Talleres-Escuela de Artes Gráficas del Colegio Don Bosco, 1978.

La colina que da al mar azul. La Paz: El Hombrecito Sentado, 1993.

Frondas nocturnas. La Paz: Creativa, 2008.

El árbol de la tribu. 2004. La Paz: Plural, 2012.

Senderos. La Paz: la mariposa mundial, 2015.

"El manuscrito de un caballo".Hipótesis, Núm. 3 (1977): 157-65.

“Animal antiguo”. Signo. Nueva época, Núm. 16 (1985): 139.

“La silla”. Signo. Nueva época, Núm. 20 (1987): 131-133.

“Árbol nocturno”. Casa de poesía Silva, № 8 (1995): 15. 